\title{
Phytochemical Screening and Acute Toxicity of Aqueous Extract of Leaves of Conocarpus erectus Linnaeus in Swiss Albino Mice
}

\author{
DAYANE K.D. NASCIMENTO ${ }^{1}$, IVONE A. DE SOUZA ${ }^{2}$, ANTÔNIO F.M. DE OLIVEIRA ${ }^{3}$, \\ MARIANA O. BARBOSA ${ }^{3}$, MARLLON A.N. SANTANA ${ }^{1}$, DANIEL F. PEREIRA JÚNIOR ${ }^{1}$, \\ EDUARDO C. LIRA ${ }^{4}$ and JEYMESSON R.C. VIEIRA ${ }^{1}$
}

\author{
${ }^{1}$ Departamento de Histologia e Embriologia, Universidade Federal de Pernambuco, Av. Prof. \\ Moraes Rego, 1235, Cidade Universitária, 50760-420 Recife, PE, Brasil \\ ${ }^{2}$ Departamento de Antibióticos, Universidade Federal de Pernambuco, Av. Prof. Moraes \\ Rego, 1235, Cidade Universitária, 50670-901 Recife, PE, Brasil \\ ${ }^{3}$ Departamento de Botânica, Universidade Federal de Pernambuco, Av. Prof. Moraes \\ Rego, 1235, Cidade Universitária, 50670-901 Recife, PE, Brasil \\ ${ }^{4}$ Departmento de Fisiologia e Farmacologia, Universidade Federal de Pernambuco, Av. Prof. \\ Moraes Rego, 1235, Cidade Universitária, 50670-901 Recife, PE, Brasil
}

Manuscript received on July 14, 2015; accepted for publication on November 27, 2015

\begin{abstract}
Mangroves represent areas of high biological productivity and it is a region rich in bioactive substances used in medicine production. Conocarpus erectus (Combretaceae) known as button mangrove is one of the species found in mangroves and it is used in folk medicine in the treatment of anemia, catarrh, conjunctivitis, diabetes, diarrhea, fever, gonorrhea, headache, hemorrhage, orchitis, rash, bumps and syphilis. The present study aimed to investigate the acute toxicity of aqueous extract of leaves of $C$. erectus in Swiss albino mice. The plant material was collected in Vila Velha mangroves, located in Itamaracá (PE). The material was subjected to a phytochemical screening where extractive protocols to identify majority molecules present in leaves were used. The evaluation of acute toxicity of aqueous extract of C. erectus followed the model of Acute Toxicity Class based on OECD 423 Guideline, 2001. The majority molecules were identified: flavonoids, tannins and saponins. The $\mathrm{LD}_{50}$ was estimated at 2,000 $\mathrm{mg} / \mathrm{kg} \mathrm{bw}$. Therefore, the aqueous extract showed low acute toxicity classified in category 5 .
\end{abstract}

Key words: acute toxicity, aqueous extract, Conocarpus erectus, medicinal plants, plants extracts.

\section{INTRODUCTION}

Conocarpus erectus L., popularly known as mangrove button belongs to the family Combretaceae and it is found in tropical and subtropical regions around the world (Bandeira 2003). Different parts

Correspondence to: Jeymesson Raphael Cardoso Vieira

E-mail: jeymesson@gmail.com as leaves, stem, fruits and flowers have antioxidant, anticancer and antimicrobial properties (Abdel-Hameed et al. 2011). In folk medicine, it was reported to astringent, styptic and tonic preventing anemia, catarrh, conjunctivitis, diabetes, diarrhea, fever, gonorrhea, headache, hemorrhage, orchitis, prickly heat, swellings and syphilis (Abdel-Hameed et al. 2013). 
Therefore, the determination of acute toxicity is the first step in toxicological investigations of aqueous extract of Conocarpus erectus L., constituting a preliminary pharmacognostic, exploring resources manipulated by the population.

\section{MATERIALS AND METHODS}

\section{PLANT MATERIALS}

Conocarpus erectus L. leaves were collected in mangrove located in Vila Velha, Itamaracá-PE, Brazil, in December 2013. Voucher specimens was identified and deposited at Herbarium of the Federal University of Pernambuco with number UFP 75.457.

\section{EXTRACTION OF CONOCARPUS ERECTUS LEAVES}

The extract was prepared by infusion from $260 \mathrm{~g}$ of fresh leaves of $C$. erectus L. The material was weighed, ground and the infusion was performed by adding distilled water at $100^{\circ} \mathrm{C}$ for 30 minutes. The aqueous extract was lyophilized and stored at $5^{\circ} \mathrm{C}$. The ratio of extraction was $1.38 \%$.

\section{EXPERIMENTAL ANIMALS}

Nine female Swiss albino mice (Mus musculus) were used, aged 11 weeks, weighing on average $38.5 \mathrm{~g}$ from the Department of antibiotics from
Universidade Federal de Pernambuco (UFPE). The animals were divided into three groups of three animals: control group (G1), treated group with $5,000 \mathrm{mg} / \mathrm{kg}$ of aqueous extract of $C$. erectus L. (G2) and treated group with $2,000 \mathrm{mg} / \mathrm{kg}$ of aqueous extract of $C$. erectus L. (G3). The animals were kept under normal conditions of temperature and humidity under natural light-dark cycle of 12 hours and given water and diet (Purina) ad libitum. Experiments with animals were performed according to the Organization for Economic Cooperation and Development (OECD 2001) and with the approval of the Ethics Committee on Animal Experimentation from UFPE under the number 23076.025194/2012-10.

\section{PHYTOCHEMICAL TEST}

Phytochemical screening of the aqueous extract of leaves of $C$. erectus L. by infusion through thin layer chromatography was performed. The presence of saponins was performed according to Harbone (1982). Silica gel plates were used $20 \times 20 \mathrm{~cm}(0.25$ $\mathrm{mm}$ thick) with suitable developers and development system employing chromatographic patterns as shown in Table I (Harbone 1982, Wagner et al. 1984, Wagner 1996) where we investigated the presence of: alkaloids, coumarins flavonoids, triterpenes, saponins and tannins.

TABLE I

Metabolites eluting system developers and used for photochemical screening of the aqueous extract of Conocarpus erectus.

\begin{tabular}{|c|c|c|c|}
\hline METABOLITES & SYSTEM ELUTION & REVEALING & REFERENCES \\
\hline Alkaloids & $\begin{array}{l}\text { AcOEt-HCOOH-AcOH-H}{ }_{2} \mathrm{O} \\
(100: 11: 11: 27 \mathrm{v} / \mathrm{v})\end{array}$ & Dragendoff & Harbone 1982 \\
\hline Coumarins & Éter-tolueno-AcOH 10\% (50:50:50v/v) & $\begin{array}{l}\mathrm{KOH}- \\
\mathrm{ETOH} 10 \%\end{array}$ & Harbone 1982 \\
\hline Flavonoids & $\begin{array}{l}\text { AcOEt-HCOOH-AcOH-H}-\mathrm{O} \\
(100: 11: 11: 27 \mathrm{v} / \mathrm{v})\end{array}$ & Difenilborilo-xiietilamina & Harbone 1982 \\
\hline Saponins & $\begin{array}{l}\text { AcOHt-HCOOH-AcOH-H}{ }_{2} \mathrm{O} \\
(100: 11: 11: 27 \mathrm{v} / \mathrm{v})\end{array}$ & $\begin{array}{l}\text { Vanilina } \\
\text { Sulfúrtica }\end{array}$ & Harbone 1982 \\
\hline Tannins & $\mathrm{CHCl} 3-\mathrm{CH} 3 \mathrm{OH}-\mathrm{H}_{2} \mathrm{O}(65: 30: 05 \mathrm{v} / \mathrm{v})$ & $\begin{array}{l}\text { Cloreto Férrico } \\
1 \%\end{array}$ & Wagner 1996 \\
\hline Triterpenes & $\begin{array}{l}\text { AcOEt-HCOOH-AcOH-H}-\mathrm{O} \\
(100: 0.5: 0.5: 0.5 \mathrm{v} / \mathrm{v})\end{array}$ & Lieberman/Burchard & Wagner et al. 1984 \\
\hline
\end{tabular}




\section{TOXICOLOGICAL ANALYSIS}

To establish the $\mathrm{LD}_{50}$ (median lethal dose) was used the methodology of according with Acute Toxic Class Method (OECD 2001) for acute toxicity test of single dose (Guideline 423). In this acute toxicity study, the initial dose of $5,000 \mathrm{mg} / \mathrm{kg}$ bw was used due to known information about toxicity of the plant (Abdel-Hameed et al. 2013). The next tested dose $2,000 \mathrm{mg} / \mathrm{kg}$ b.w. was selected depending on the mortality observed in the first 24 hours of exposure, and finally was estimated toxicological category, according to the specifications of OECD (2001). The control group received distilled water orally with corresponding dose to the body weight of the animal.

\section{RESULTS}

\section{PHYTOCHEMICAL SCREENING}

The aqueous extract of $C$. erectus L. showed the presence of flavonoids, tannins and saponins and absence of alkaloids, coumarins, and triterpenes (Figure 1).

\section{TOXIC SIGNS AND BEHAVIORAL ANALYSIS}

The Toxic Signs and Behavioral Analysis were performed according to Malone (1977). The toxic effects of aqueous extract of $C$. erectus $\mathrm{L}$. in mice are shown in Table II. The G1 group did not show behavioral changes. In G2 the animals showed stimulants effects as: increased respiratory frequency, piloerection, stereotyped movement, tail erection, sweep, vibrissae movement and tail contraction; depressant effects as: dyspnea, change gear and prostration; and others effects such as: photophobia, spasms, contortion abdominal, abdominal distension, reflux, escape reaction, cyanosis, muzzle edema, pallor and vocal tremor. In G3 group the animals showed stimulants effects as: increased respiratory frequency, piloerection, stereotyped movement, fine tremors, erection tail, sweep, movement vibrissae, attack posture and lifting upper train; depressant effects as: change gear and prostration; and others effects such as: photophobia, spasms, contortion abdominal, abdominal distension, reflux, exploratory behavior, escape reaction, muzzle edema, pallor and vocal tremor.

\section{ACUTE TOXICITY}

In group treated with $5,000 \mathrm{mg} / \mathrm{kg}(\mathrm{G} 2)$, the first animal dosed survived, then two further animals were dosed and both died. The dosing processed at $2,000 \mathrm{mg} / \mathrm{kg}(\mathrm{G} 3)$ and $100 \%$ of animals survived. Therefore, the $\mathrm{LD}_{50}$ of the aqueous extract of $C$. erectus is estimated in $2,000 \mathrm{mg} / \mathrm{kg}$, being classified according to the Globally Harmonized System for

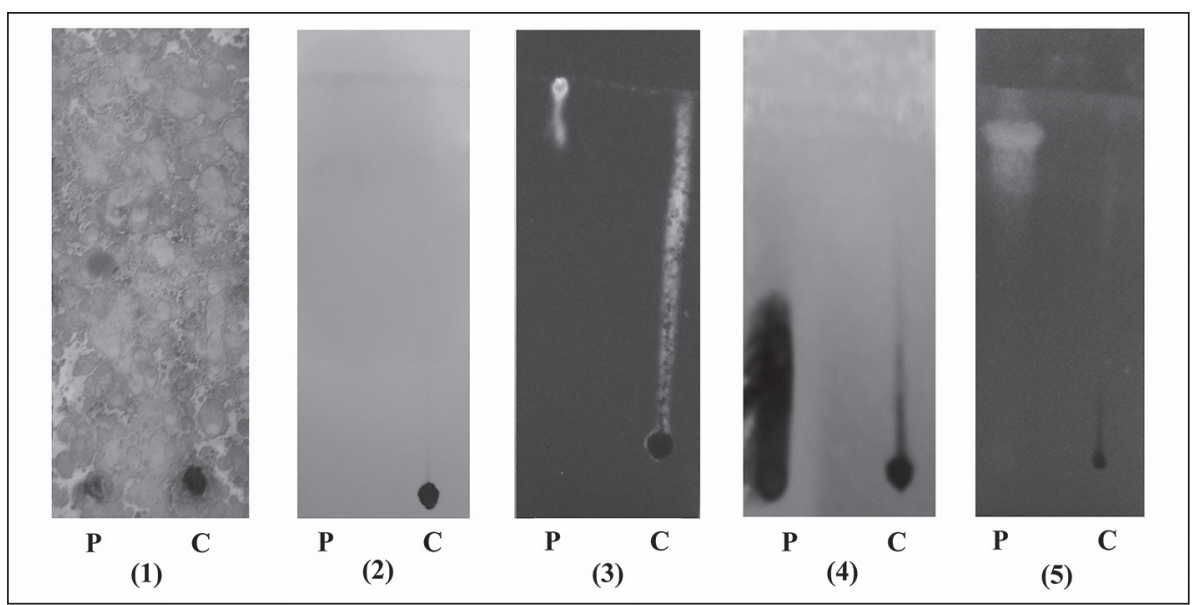

Figure 1 - Chromatogram of Alkaloids, Coumarins, Flavonoids, Tannins and Triterpenes. 
TABLE II

Parameters related to toxic signs and behavioral analysis in swiss albino female mice assessed during sixty minutes after the oral administration of the aqueous extract of $C$. erectus 1 . in doses of $2,000 \mathrm{mg} / \mathrm{kg}$ bw and $5,000 \mathrm{mg} / \mathrm{kg} \mathrm{bw}$.

\begin{tabular}{|c|c|c|c|c|c|c|}
\hline \multirow[t]{3}{*}{ PARAMETERS } & \multicolumn{6}{|c|}{ DOSAGE } \\
\hline & \multicolumn{3}{|c|}{$2,000 \mathrm{mg} / \mathrm{kg}$} & \multicolumn{3}{|c|}{$5,000 \mathrm{mg} / \mathrm{kg}$} \\
\hline & $\mathrm{CM}$ & $\mathrm{RM}$ & DM & $\mathrm{CM}$ & RM & $\mathrm{DM}$ \\
\hline \multicolumn{7}{|l|}{ STIMULANTS } \\
\hline Increased Respiratory Frequency & + & ++ & +++ & - & - & +++ \\
\hline Piloerection & ++ & ++ & ++ & - & +++ & +++ \\
\hline Exophthalmia & - & - & - & - & - & - \\
\hline Stereotyped movement & +++ & +++ & ++ & +++ & +++ & ++ \\
\hline Fine tremors & - & - & + & - & - & - \\
\hline Tail erection & + & + & + & + & +++ & - \\
\hline Sweep & + & +++ & + & + & ++ & +++ \\
\hline Vibrissae movement & + & +++ & + & ++ & ++ & + \\
\hline Agitation & - & - & - & - & - & - \\
\hline Tail contraction & - & - & - & - & + & - \\
\hline Fail curling & - & - & - & - & - & - \\
\hline Attack posture & + & ++ & - & - & - & - \\
\hline Heels & - & - & - & - & - & - \\
\hline Lifting upper train & + & - & - & - & - & - \\
\hline \multicolumn{7}{|l|}{ DEPRESSANT } \\
\hline Decreased respiratory frequency & - & - & - & + & - & - \\
\hline Dyspnea & - & - & - & - & - & +++ \\
\hline Prostration & +++ & ++ & ++ & +++ & ++ & +++ \\
\hline Change gear & ++ & ++ & + & + & - & +++ \\
\hline Lowering hindquarters & - & - & - & - & - & - \\
\hline \multicolumn{7}{|l|}{ OTHERS } \\
\hline Photophobia & +++ & +++ & ++ & - & +++ & +++ \\
\hline Spasms & ++ & + & ++ & ++ & + & +++ \\
\hline Fecal excretion & - & - & - & - & - & + \\
\hline Ciarrhea & - & - & - & - & - & - \\
\hline Diurese & - & - & - & - & - & - \\
\hline Contortion abdominal & + & - & - & - & - & + \\
\hline Abdominal distension & - & + & - & - & + & + \\
\hline Reflux & +++ & +++ & +++ & - & - & +++ \\
\hline Exploratory Behavior & + & - & + & - & - & - \\
\hline Escape Reaction & +++ & + & + & +++ & + & + \\
\hline Aggressiveness & - & - & - & - & - & - \\
\hline Cyanosis & - & - & - & + & +++ & + \\
\hline Muzzle edema & + & + & + & ++ & - & +++ \\
\hline Petechiae & - & - & - & - & - & - \\
\hline CHANGE: Depression x Shake & - & - & - & - & - & - \\
\hline Pallor & - & + & + & - & ++ & +++ \\
\hline Vocal tremor & - & - & + & + & + & +++ \\
\hline DEATH & - & - & - & - & + & + \\
\hline
\end{tabular}

- = no effect $\quad+=$ low effect $\quad++=$ moderate effect $\quad+++=$ high effect (Malone 1977). 
Classification and Labeling of Chemicals (2015) as low toxicity and belonging to category 5 according to the criteria of the experimental protocol adopted.

\section{DISCUSSION}

The phytochemical investigation shows that aqueous extracts of Conocarpus erectus revealed presence of flavonoids, tannins and saponins and absence of alkaloids, coumarins, and triterpenes.

Phytochemical studies of the methanol extract and n-hexane of leaves of Conocarpus erectus indicated the presence of triterpenes in n-hexane extract and absence of saponins in the methanol extract (Bandeira 2003).

This fact reinforces the proposal by GobboNeto and Lopes (2007) of the need for studies that assess the differences in chemical composition between organs of the same plant, different times of collection, different cultivation environments and even different forms of nutrition plant used. The secondary metabolites represent a chemical interface between plants and the surrounding environment, so their synthesis are often affected by environmental conditions such as rainfall, U.V. radiation, atmospheric composition, circadian rhythm, plant age and temperature.

Reports about phytochemical evaluations of aqueous extract of leaves of $C$. erectus were not found in the literature and it makes difficult a comparison of the results with others using the same conditions.

Studies on extracts of leaves of $C$. erectus L. showed antimicrobial, antioxidant, anticancer, hepatoprotective and astringent properties (Bandeira 2003, Abdel-Hameed et al. 2011, 2013, Shohayeb et al. 2013). However, pharmacological proprieties can be associated with phytochemical compounds found in this study such as flavonoids which have antioxidant, anti-inflammatory and hepatoprotective properties (Lopes et al. 2000) saponins, related to antimicrobial and anti-inflammatory activities
(Müller 2006) and tannins with antimicrobial and astringent activities (Monteiro et al. 2005).

After oral administration of the substance, significant changes were observed in the behavioral parameters of mice, mainly in central nervous system, autonomic nervous system and somatomotor activity.

However, it is possible that the saponins could elevate the toxic effects due to its emollient or stimulant properties (Akah and Offiah 1992).

The evaluation of acute toxicity is a methodology widely used to identify and classify substances as to their ability to cause acute damage to living organisms, in high doses, especially anatomicalpathological and lethal injuries, and can offer assistance to establish security parameters along with other toxicity data to human health (Valadares 2006, Zatta et al. 2009).

For vegetables, the method is useful for identifying the toxicity that may exhibit and minimize the misconception of the population into believing that natural products are devoid of toxic or adverse effects (Cunha et al. 2013)

Information about lethal doses of $C$. erectus $\mathrm{L}$. is known in literature (Abdel-Hameed et al., 2013). According to the guide of OECD, Guideline 423 (OECD 2001), when available information about the tested plant suggests that mortality is unlikely at the highest starting dose level $(2,000 \mathrm{mg} / \mathrm{kg})$, then a limit test should be conducted.

The present study concerning to investigation of toxicity of the aqueous extracts of $C$. erectus leaves revealed low acute toxicity, classified in category 5 and $\mathrm{LD}_{50}$ estimated at $2,000 \mathrm{mg} / \mathrm{kg}$ bw.

Our results do not corroborate those obtained by Abdel-Hameed (2013) who studied leaves, stems, flowers and fruits of $C$. erectus $\mathrm{L}$. and showed that methanol extracts did not induce mortality in Swiss albino mice at doses from 500 $\mathrm{mg} / \mathrm{kg}$ to $5,000 \mathrm{mg} / \mathrm{kg}$ intraperitoneally during $24 \mathrm{~h}$ of observation, then the extracts did not show acute toxicity with $\mathrm{LD}_{50}>5,000 \mathrm{mg} / \mathrm{kg}$. 
Differences on route of administration, time of observation or solvent used to prepare the extract may result in unintentional adverse effects on experimental animals and confounded results. According to Turner et al. (2011), specific considerations for delivery of substances to animals are numerous and include factors such as absorption, distribution, metabolism and excretion of therapeutic or chemical agents; route, volume, and frequency of administration; duration of treatment; $\mathrm{pH}$, stability, homogeneity, and osmolality of the substance to be administered; selection of vehicle or solvent for delivering substances that cannot be administered in a solid or particulate state; solution preparation. Some of those aspects could have influenced in divergences of results.

However, further studies should be conducted to perform the histomorphometry of the liver and kidneys from the animals to check possible pathological changes.

\section{CONCLUSIONS}

Chemical Constituents identified in the aqueous extract of leaves of Conocarpus erectus L. species were flavonoids, saponins and tannins. The extract was classified as belonging to category 5 with a low toxicity. The $\mathrm{LD}_{50}$ of the aqueous extracts Conocarpus erectus L. was estimated at $2,000 \mathrm{mg} /$ $\mathrm{kg}$ body weight.

\section{ACKNOWLEDGMENTS}

We would like to thank the biologist Marlene Barbosa for the identification of the plant and the biology student Pedro Neto for their assistance in collection of the plant.

\section{REFERENCES}

ABDEL-HAMEED ES, ABDEL SAB AND SABRA NA. 2013. Protective Effect of Conocarpus erectus Extracts on $\mathrm{CCl}$ 4-Induced Chronic Liver Injury in Mice. Global J Pharm 7: 52-60.
ABDEL-HAMEED ES, BAZAID SA, SHOHAYEB MM, ELSAYED MM AND EL-WAKIL EA. 2011. Phytochemical Studies and Evaluation of Antioxidant, Anticancer and Antimicrobial Properties of Conocarpus erectus L. Growing in Taif. European J Medic Plan 2: 93-112.

A GUIDE TO THE GLOBALLY HARMONIZED SYSTEM OF CLASSIFICATION AND LABELLING OF CHEMICALS. 2015. Available in: <https://www. osha.gov/dsg/hazcom/ghsguideoct05.pdf $>$. Accessed in September $25^{\text {th }}, 2015$.

AKAH PA AND OFFIAH VN. 1992. Gastrointestinal effects of Allamanda cathartica leaf extracts. Inter J Pharmac 30: 213-217.

BANDEIRA ARG. 2003. Estudo Fitoqúimico e a Atividade Biológica de Conocarpus erectus L. (Mangue Botão). Recife (PE): Universidade Federal de Pernambuco, 86 p.

CUNHA LC, MELO DCA, PEREIRA ME, MELO DS, PARENTE LL, SILVA MAC, CONCEIÇÃO EC AND GONZAGA LQS. 2013. Avaliação da toxicidade aguda do extrato aquoso de Apeiba tibourbou Aubl (Tiliceae), em camundongos e ratos. Rev Ciênc Farm Apl 34: 357-362.

GOBBO-NETO L AND LOPES NP. 2007. Plantas medicinais: fatores de influência no conteúdo de metabólitos secundários. Quím Nova 30: 374-381.

HARBORNE JB. 1982. Phytochemical Methods: a guide to modern techniques of plant analysis, $2^{\text {nd }}$ ed., Londres: Publisher Chapman \& Hallde, $278 \mathrm{p}$.

LOPES RM, OLIVEIRA TT, NAGEM TJ AND PINTO AS. 2000. Flavonóides: farmacologia de flavonoides no controle hiperlipidêmico em animais experimentais. Rev Biotec Cien \& Desenv 3: 18-22.

MALONE MH. 1977. Pharmacological approaches to natural product, screening and evaluation. In: Wagner $\mathrm{H}$ and Wolf P (Eds), Natural Products and Plant Drugs with Pharmacological, Biological or Therapeutical Activity, SpringerVerlag, Berlin, p. 23-53.

MONTEIRO JM, ALBUQUERQUE UP AND ARAÚJO EL. 2005. Taninos: uma abordagem da química à ecologia. Quím Nov: 892-896.

MÜLLER JB. 2006. Avaliação das atividades antimicrobiana, antitoxidante e antinociceptiva das folhas da Luehea divaricata Martius. Universidade Federal de Santa Maria, 99 p.

OECD - ORGANISATION FOR ECONOMIC CO-OPERATION AND DEVELOPMENT. 2001. Guidelines for the Testing of Chemicals, OECD 423. Acute Oral ToxicityAcute Toxic Class Method. Paris: Organisation for Economic Cooperation and Development.

SHOHAYEB M, ABDEL-HAMEED E AND BAZAID AS. 2013. Antimicrobial Activity Of Tannins and Extracts Of Different Parts Of Conocarpus Erectus L. Inter J Pharm Biol Scien 3: 544-553.

TURNER PV, BRABB T, PEKOW C AND VASBINDER MA. 2011. Administration of Substances to Laboratory Animals: Routes of Administration and Factors to Con- 
sider. Available in: <http://www.ncbi.nlm.nih.gov/pmc/articles/PMC3189662/>. Accessed in September 25th, 2015.

VALADARES MC. 2006. Avaliação de Toxicidade Aguda: Estratégias Após a "Era do Teste $\mathrm{DL}_{50}$ ". Rev Eletr Farm 3: 93-98.

WAGNER H AND BLADT S. 1996. Plant Drugs Analysis - A Thin Layer Chromatography Atlas. $2^{\text {nd }}$ ed., Berlin: Publisher Springer Verlag, 384 p.
WAGNER H, BLADT S AND ZGAINSKI EM. 1984. Drongenanalyse. Berlin: Publisher Springer-Verlag, $164 \mathrm{p}$. ZATTA DT, PIMENTA FC, TRESVENZOL LMF, FIUZA TS, BARA MTF, CUNHA LC, PUCCI, LL, GARROTE CFD, OLIVEIRA FNM AND PAULA JR. 2009. Estudo da Atividade Antibacteriana contra cepas de Pseudomonas aeruginosa e da Toxicidade Aguda das folhas da Jacaranda decurrens. Latin Am J Pharm 28: 485-489. 